\title{
Differential Expression of Op18 Phosphoprotein during Human Thymocyte Maturation
}

\author{
Jeanne Gratiot-Deans, * David Keim, ${ }^{\mathbf{*}}$ John R. Strahler, ${ }^{*}$ Laurence A. Turka, * and Samir Hanash* \\ Departments of * Internal Medicine and ${ }^{\ddagger}$ Pediatrics, University of Michigan Medical School, Ann Arbor, Michigan 48109
}

\begin{abstract}
Op18 (also termed prosolin/stathmin) is a highly conserved 18-kD cytosolic phosphoprotein expressed in low levels in mature resting G0 lymphocytes, but induced in late $\mathbf{G 1}$ and $\mathrm{S}$ phases after entry into the cell cycle. In addition to its induction in normal proliferating lymphocytes, Op18 has been found to occur at high levels in acute leukemias and in neuroendocrine tissue. The presence and rapid phosphorylation of Op18 after stimulation of proliferating cells correlates with subsequent functional responses of the cells, and, therefore, 0 p18 has been suggested to play a key role in signal transduction. The pattern of expression of Op18 during lymphoid development is of interest in view of its high levels of expression in acute leukemias, representing cells arrested at an immature stage, thus raising the possibility that Op18 may be regulated differently in mature and immature lymphoid cells. We report here that immature human thymocytes bearing the cortical double positive phenotype $\left(\mathrm{CD4}^{+} \mathrm{CD8}^{+}\right)$constitutively express high levels of Op18 protein. In contrast, in mature single positive thymocytes $\left(\mathrm{CD3}^{+} \mathrm{CD4}^{+}\right.$or $\left.\mathrm{CD3}^{+} \mathrm{CD8}^{+}\right), 0$, 18 protein is expressed at a lower level, comparable to that seen in peripheral blood $\mathrm{T}$ cells. Cell cycle analysis demonstrated that most of the cells in the double positive thymocyte population expressing high levels of Op18 were noncycling and arrested in G0. Furthermore, there was no correlation between $0 p 18$ levels and the proportion of cycling cells in double positive thymocyte populations isolated from different thymuses. Interestingly, although Op18 protein levels did not increase any further after mitogenic stimulation of double positive thymocytes, an increase in Op18 phosphorylation was observed, thus coupling of Op18 phosphorylation to cell activation remained intact. Our results show that during lymphoid maturation Op18 expression is uncoupled from cell proliferation. These data also suggest that the ordered expression of proliferation-associated genes seen in mature $\mathbf{T}$ cells may be disrupted during $\mathrm{T}$ cell maturation. (J. Clin. Invest. 1992. 90:1576-1581.) Key words: $T$ cell ontogeny • cell cycle • proliferation • 2-D PAGE • leukemia
\end{abstract}

Address correspondence to Laurence A. Turka, Division of Nephrology, Division of Nephrology, Department of Internal Medicine, 1560 Medical Research Building II, 1150 W. Medical Center Drive, Ann Arbor, MI 48109.

David Keim's current address is Division of Immunology \#50, Children's Memorial Hospital, 2300 Children's Plaza, Chicago, IL 60614.

Received for publication 6 February 1992 and in revised form 28 April 1992.

J. Clin. Invest.

(C) The American Society for Clinical Investigation, Inc.

$0021-9738 / 92 / 10 / 1576 / 06 \$ 2.00$

Volume 90, October 1992, 1576-1581

\section{Introduction}

Op18 is a highly conserved $18-\mathrm{kD}$ cytosolic phosphoprotein whose expression has been found to correlate closely with the proliferative status of both normal and malignant tissues. Op 18 is normally expressed in low levels in resting G0 T cells, and is strongly induced after mitogenic stimulation of these cells, with maximal levels of expression seen in late $G 1$ and early $S$ phases of the cell cycle (1-5). Thus, the gene for Op18, like those for several other proteins including the cyclins and cdc2 kinase (6, 7 ), has been considered to be a "proliferation-induced" gene. Consistent with this, regulation of Op 18 expression occurs primarily at the levels of transcription (5), and transformed cells express elevated levels of a structurally unaltered gene (5). Induction of terminal differentiation in leukemic cells results in a down-regulation of Op18 expression (8).

Several studies have suggested that Op1 8 may function as a key signal transducing molecule after cell stimulation. Activation of lymphocytes by monoclonal antibodies to the $T$ cell receptor (TCR $)^{1}$ by lectins or by phorbol esters induces serine/ threonine phosphorylation of Op 18 generating several distinct forms designated Op18, a, -b, and -c (9). This is observed before induction of Op 18 synthesis and occurs as early as 2 min after stimulation of the T cell receptor/CD3 complex (TCR/ CD3) (9). Inhibition of proliferation after activation of leukemic cells or proliferating normal lymphoblasts is associated with Op18 phosphorylation $(10,11)$, and alterations in Op18 phosphorylation have been found to be associated with impairment of this response (12). Finally, blockade of Op18 mRNA translation using antisense oligonucleotides delays the entrance of resting lymphocytes into $S$ phase after mitogenic stimulation (8).

The putative role of Op18 in signal transduction, and its overexpression in lymphoid cells with a maturational arrest (e.g., T cell acute lymphoblastic leukemia) (1) led us to study the expression of Op 18 during normal lymphoid development. For $\mathrm{T}$ cells, maturational stages of thymocytes can be assigned based on surface expression of the TCR/CD3 complex and the accessory molecules CD4 and CD8. Before recombination of the TCR genetic elements, cells express neither CD3, CD4, nor CD8 on the cell surface (13) (Fig. 1). As maturation continues, cells coexpress both the CD4 and CD8 molecules $\left(\mathrm{CD} 4{ }^{+} \mathrm{CD} 8{ }^{+}\right.$, "double positive cells"), and after productive TCR gene recombination, they also display the TCR/CD3 complex on their cell surface (14). With further maturation and selection, the thymocytes increase expression of TCR/ CD3 and lose $\mathrm{CD} 4$ or $\mathrm{CD} 8\left(\mathrm{CD} 3^{+ \text {(bright) }} \mathrm{CD} 4^{+} \mathrm{CD} 8^{-}\right.$or $\mathrm{CD}^{+ \text {(bright) }} \mathrm{CD}^{-}{ }^{-} \mathrm{CD} 8^{+}$, "single positive cells") (15). Single positive thymocytes are primarily found in the thymic medulla

1. Abbreviations used in this paper: 2-D PAGE, two dimensional PAGE; PE, phycoerythrin; PMA, phorbol 12-myristate 13-acetate; RII, relative integrated intensity; TCR, T cell receptor. 


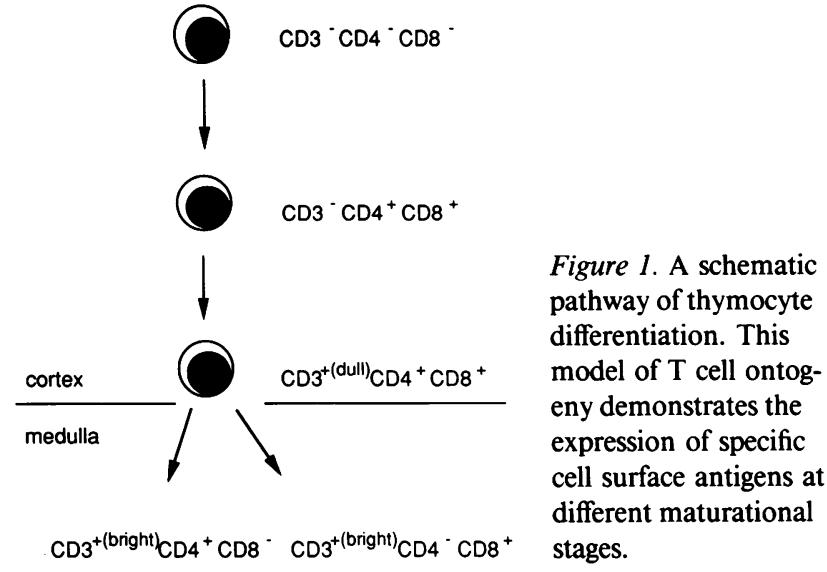

and represent mature MHC-restricted thymocytes that are phenotypically identical to peripheral blood $T$ cells (15).

In this study, we have examined the relationship between Op18 expression and lymphoid development using human thymic tissue. Our results demonstrate that in freshly isolated immature double positive thymocytes, $\mathrm{Op} 18$ is expressed in high levels independent of proliferation, while in mature single positive thymocytes that are phenotypically similar to peripheral blood T cells, Op18 is expressed in low levels and is induced after mitogenic stimulation. Thus, the regulation of Op 18 expression is not coupled to cell cycle progression during $\mathrm{T}$ cell ontogeny. These findings indicate that $\mathrm{Op} 18$ expression may be differentially regulated during development and after the maturation of lymphoid cells, and the previously described association of high levels of $\mathrm{Op} 18$ expression with cell proliferation is not applicable to immature T cells.

\section{Methods}

$m A b$. The mouse anti-human mAbs 9.3 (anti-CD28), G19-4 (antiCD3), G17-2 (anti-CD4) and G10-1 (anti-CD8) were a gift of Dr. Jeffrey Ledbetter, and T6 (anti-CD1) was a gift of Dr. Patricia Rao. FITC- and phycoerythrin (PE)-labeled goat anti-mouse antibodies were purchased from Tago, Inc. (Burlingame, CA). Goat anti-mouse coated magnetic beads were purchased from Advanced Magnetics, Inc., ( Cambridge, MA).

Reagents. PMA (phorbol 12-myristate 13-acetate), propidium iodide, and acridine orange were purchased from Sigma Chemical Co. (St. Louis, MO). Ionomycin was purchased from Calbiochem Corp. (San Diego, CA).

Isolation of thymocytes. Thymic tissue was obtained from children under age 6 undergoing corrective surgery, and a suspension of unfractionated thymocytes was prepared as previously described (16). To obtain cells at distinct maturational stages, two different strategies for cell isolation were used. Double positive and single positive thymocytes were isolated by negative selection for CD28 or CD1, respectively, since CD28 is expressed at high levels only on single positive thymocytes (16), whereas CD1 is expressed on double positive thymocytes, but is absent from the surface of single positive thymocytes (17). Negative selection with $\mathrm{CD} 1$ or $\mathrm{CD} 28$ was performed using goat anti-mouse lg-coated magnetic beads as described (18). The most immature thymocytes, those that are $\mathrm{CD} 3^{-} \mathrm{CD} 4^{-} \mathrm{CD} 8^{-}$, express neither $\mathrm{CD} 1$ nor CD28 ( 17 and Turka, L.A., unpublished observations). These are present in very small numbers $(1-2 \%)$ in the human postnatal thymus and do not result in significant levels of contamination of $\mathrm{CD1}^{-}$or $\mathrm{CD} 28^{-}$ preparations. To study $\mathrm{CD}^{-}{ }^{-} \mathrm{CD} 4^{-} \mathrm{CD} 8^{-}$thymocytes, this population was separately isolated by negative selection with $\mathrm{CD} 3, \mathrm{CD} 4$, and CD8. To insure that the results obtained using double positive cells isolated by negative selection with CD28 were not secondary to an artifact of cell separation, in some experiments double positive thymocytes (both
$\mathrm{CD}^{+}$and $\mathrm{CD}^{-}$) were directly isolated by positive and negative selection with $\mathrm{CD} 3, \mathrm{CD} 4$, and CD8. Separations using CD3, CD4, or CD8 were done by panning (16). Cell purity was monitored by using indirect immunofluorescent staining and flow cytometric analysis.

Cell culture. Thymocytes were cultured in complete medium consisting of RPMI $1640,10^{5} \mathrm{U} /$ liter penicillin, $100 \mathrm{mg}$ /liter streptomycin, $5 \mathrm{mM}$ Hepes, $2 \mathrm{mM}$ L-glutamine, and $10 \%$ FCS. All products were purchased from Gibco Laboratories (Grand Island, NY). Cells were cultured at a density of $1 \times 10^{6} / \mathrm{ml}$. When specified, PMA $(10 \mathrm{ng} / \mathrm{ml})$ and ionomycin $(250 \mathrm{ng} / \mathrm{ml})$ were added to the culture media.

Analysis of cell surface phenotype. $1 \times 10^{6}$ cells were mixed with a saturating amount of the apropriate FITC- or PE- conjugated antibody and suspended in $100 \mu \mathrm{l}$ of a solution containing $50 \%$ FCS, 50\% PBS, and $0.1 \%$ sodium azide, incubated for $45 \mathrm{~min}$, washed, and resuspended in $0.5 \mathrm{ml}$ PBS with $1 \%$ formaldehyde for flow cytometric analysis (16). When unlabeled mAb were used, cells were first incubated as indicated above with the unlabeled antibody, washed twice, and stained in a similar fashion with FITC- or PE- conjugated goat antimouse antibody before fixation in $1 \%$ formaldehyde (16). Single and dual color fluorescent analyses were performed on a FACScan ${ }^{\circledR}$ (Becton Dickinson Immunocytometry Systems, Mountain View, CA).

Cell cycle analysis. $2 \times 10^{6}$ cells fixed in $70 \%$ ethanol were incubated with propidium iodide $(5 \mathrm{mg} / \mathrm{ml})$ and $R$ Nase $A(40 \mathrm{mg} / \mathrm{ml})$ overnight at $4^{\circ} \mathrm{C}$, and then analyzed by flow cytometry. For cell cycle analysis using acridine orange, $2 \times 10^{5}$ ethanol fixed thymocytes were washed and resuspended in cold PBS at a concentration of $1 \times 10^{6}$ cells $/ \mathrm{ml} .400 \mathrm{ml}$ of solution A $(0.1 \% \mathrm{vol} / \mathrm{vol}$ Triton X-100, $0.08 \mathrm{~N}$ $\mathrm{HCl}, 0.15 \mathrm{~N} \mathrm{NaCl}$ ) was added gently to the cells. After a 15-s incubation on ice, $1.2 \mathrm{ml}$ of solution $\mathrm{B}(20 \mathrm{mM}$ acridine orange, $1 \mathrm{mM}$ EDTA-Na, $0.15 \mathrm{M} \mathrm{NaCl}$, phosphate-citric acid buffer, $\mathrm{pH} 6.0$ ) was then added and the cells were incubated for another $3 \mathrm{~min}$ on ice. Dual color fluorescent analyses were performed on a FACScan ${ }^{\circledR}$ flow cytometer (Becton Dickinson), with green fluorescence specific for DNA and red fluorescence specific for RNA (19).

Proliferation assays. Thymocytes were plated at $10^{5}$ cells per well in 96-well microtiter plate in a total volume of $0.2 \mathrm{ml}$. Cells were pulsed with $1 \mu \mathrm{Ci} /$ well $\left[{ }^{3} \mathrm{H}\right]$ thymidine $6 \mathrm{~h}$ before harvest at the indicated time points, as previously described (16).

Two-dimensional PAGE (2-D PAGE). The procedure followed was as previously described (20). Cell pellets were solubilized in lysis buffer consisting of (per liter): $8 \mathrm{M}$ urea, $20 \mathrm{ml}$ Nonidet P-40 surfactant, 20 $\mathrm{ml}$ of ampholytes ( $\mathrm{pH} 3.5-10), 20 \mathrm{ml}$ of 2-mercaptoethanol, and 0.2 $\mathrm{mM}$ of PMSF in distilled deionized water. $30-\mathrm{ml}$ aliquots containing solubilized cells $\left(3 \times 10^{6}\right)$ were applied onto isofocusing gels. First dimension gels contained $50 \mathrm{ml}$ of ampholytes per liter ( $\mathrm{pH} \mathrm{3.5-10)}$. Isofocusing was done at $1,200 \mathrm{~V}$ for $16 \mathrm{~h}$ and $1,500 \mathrm{~V}$ for the last $2 \mathrm{~h}$. For the second dimension separation, an acrylamide gradient of 11.4 $14.0 \mathrm{~g} / \mathrm{dl}$ was used. Protein spots in gels were visualized by silver staining.

Quantitative analysis of Op 18 polypeptides was as previously described (21). Each gel was scanned in a 1,024 × 1,024 pixel format. Gel images were assigned coded numbers and were analyzed for the quantity of Op18 (phosphorylated and unphosphorylated) without knowledge of the sample to which an image corresponded. The integrated intensity of Op 18 polypeptides and a group of reference spots (21) were measured in units of optical density times square millimeter. The reference spots were used to adjust Op18 spot integrated intensities as previously described (21) to compensate for slight variations in protein loading or staining between gels. The adjusted values are designated relative integrated intensity.

RNA studies. Northern blots were performed as previously described (16). Briefly, RNA was extracted from $20-50 \times 10^{6}$ cells by disruption in guanidine isothiocyanate and ultracentrifugation over a cesium chloride cushion. The RNA was purified by phenol/choloroform extraction and precipitated with ethanol. Equalized RNA samples were size fractionated on $1 \%$ agarose-formaldehyde gels, transferred to nitrocellulose membranes, and sequentially probed with cDNAs labeled by random hexamer reaction. The membranes were washed and exposed to x-ray film, as previously described (16). 
DNA probes. The probes used in these experiments were gene-specific inserts isolated from low melting point agarose after digesting the plasmid in which they were propagated with the appropriate restriction endonucleases. The HLA-B7 probe was a 1.4-kb Pstl fragment isolated from pHLA-B7 (22). The Op18 probe was a 1.3-kb Xbal fragment (5).

\section{Results}

Differential expression of Op18. Purified double positive and single positive thymocytes were prepared as outlined in Methods. The extent of purity of the resultant cell fractions is shown in Fig. 2.

The location of Op18 in 2-D gels is shown in Fig. 3. In three separate experiments using different thymus specimens but with double positive and single positive cells isolated from the same thymus, there was a statistically significant sixfold difference in the relative integrated intensity (RII) of Op 18 between double positive and single positive thymocytes as detected in 2-D gels ( Table I, Fig. 3). Based on previous studies of quantitative analysis of silver stained gels, the difference in the RII between the double and single positive thymocytes corresponds to an $\sim 12$-fold difference in the amount of Op18 protein present $(21)$. In both cell types, Op1 8 occurred predominantly in the nonphosphorylated form. The observed mean RII for total Op18 in the single positive thymocytes $(1.48 \pm 0.17$, mean \pm SD) was equivalent to that observed in six separate preparations of freshly isolated peripheral blood $\mathrm{T}$ cells ( $1.34 \pm 0.62)$. Consistent with the differences in Op18 protein levels between the two thymocyte populations, Northern blot analysis revealed that steady state mRNA levels for Op18 were substantially higher in double positive thymocytes, as compared with single positive thymocytes (Fig. 4).

Double positive thymocytes are a heterogeneous group consisting of both $\mathrm{CD}^{-} \mathrm{CD}^{+}{ }^{+} \mathrm{CD}^{+}{ }^{+}$and $\mathrm{CD} 3{ }^{+} \mathrm{CD}^{+}{ }^{+} \mathrm{CD} 8{ }^{+}$ cells (Fig. 1). To determine if the observed high level of Op 18 in double positive thymocytes was specific for a single subset of cells, we isolated $\mathrm{CD}^{-} \mathrm{CD}^{+} \mathrm{CD}^{+}$(purity $>80 \%$ ) and $\mathrm{CD}^{+}{ }^{+} \mathrm{CD}^{+}{ }^{+} \mathrm{CD}^{+}{ }^{+}$(purity $>93 \%$ ) double positive thymocytes. Both sets of double positive thymocytes expressed Op 18 at high levels (Table II). The finding also serves to confirm that the high levels of Op18 seen in double positive thymocytes prepared by negative selection with CD28 were not an artifact of the cell purification procedure. We also purified the most immature thymocyte subset, $\mathrm{CD} 3^{-} \mathrm{CD} 4^{-} \mathrm{CD} 8^{-}$(purity $>84 \%$ ). These cells also expressed high levels of Op18. In all subpopulations tested, Op 18 was found predominantly in the nonphosphorylated form (Table II).

Cell cycle and proliferation analysis. Since high protein levels of Op18 have been associated with proliferating cells, we examined the cell cycle status of the double positive thymocytes in relation to the total Op18 level (Table III). While there was some variability in the proportion of cells in $\mathrm{S} / \mathrm{G} 2 / \mathrm{M}$ phases between isolates from separate thymuses, total Op18 levels were unrelated to cell cycle distribution (Table III). High Op 18 levels were observed with as little as $4 \%$ of the immature cells in S/G2/M.

Op18 is induced during $\mathrm{G} 1$ phase, and measurement of DNA content alone does not differentiate between $\mathrm{G} 0$ and $\mathrm{G} 1$. Therefore, to determine if high Op18 levels were caused by a large proportion of double positive thymocytes in G1 and not
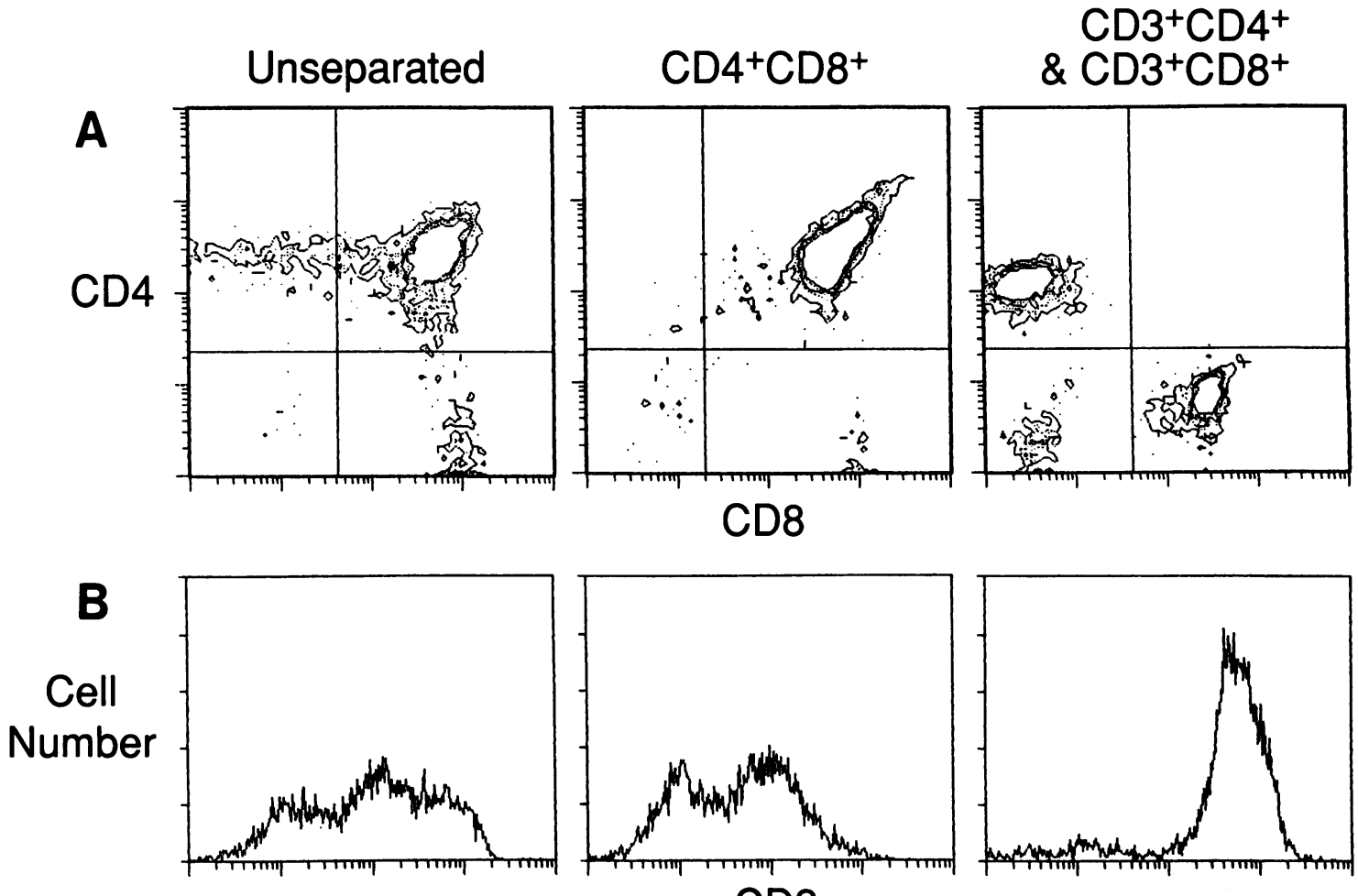

CD3

Figure 2. Phenotype of thymocyte preparations. Double positive thymocytes $\left(\mathrm{CD} 4^{+} \mathrm{CD} 8^{+}\right)$were negatively selected with anti-CD28 $\mathrm{mAb}$ and single positive thymocytes $\left(\mathrm{CD}^{+} \mathrm{CD}^{+}\right.$and $\left.\mathrm{CD}^{+} \mathrm{CD}^{+}\right)$were negatively selected with anti-CD1mAb. $(A)$ Unfractionated, double positive, and single positive thymocyte preparations were stained with FITC-labeled anti-CD8 mAb and PE-labeled anti-CD4 mAb. Double positive cells were $>92 \%$ pure with $<4 \%$ contaminating mature $\mathrm{CD} 3^{+}$single positive cells. Single positive cells were $>85 \%$ pure with $<4 \%$ contaminating double positive cells. $(B)$ The same cell fractions were stained with FITC-labeled anti-CD3 mAb. 
A

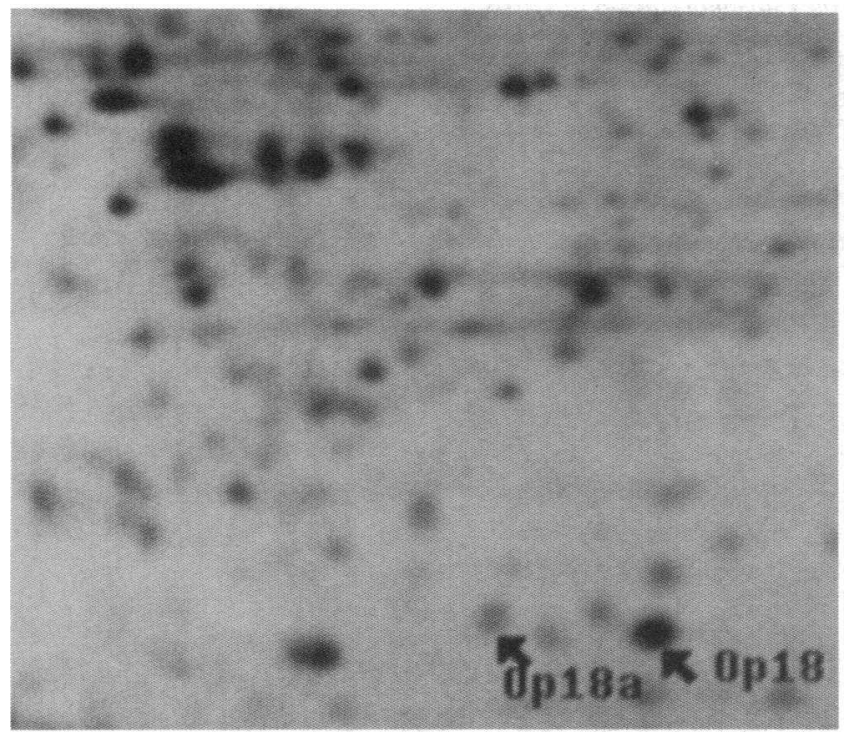

B

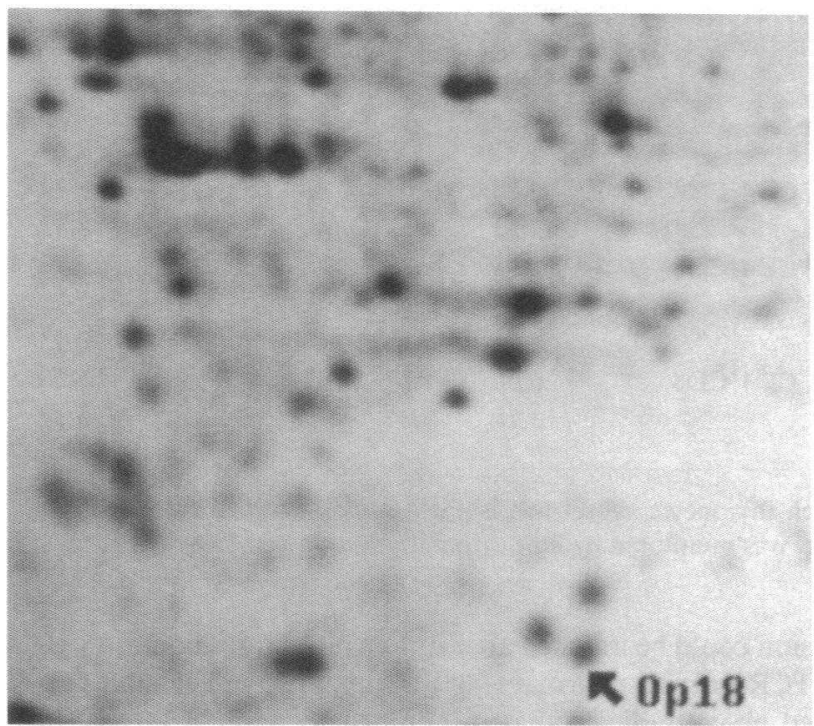

Figure 3. 2-D PAGE patterns of total cellular protein from unstimulated double positive $(A)$ and single positive $(B)$ thymocytes demonstrating the differences in Op18 levels. Op18a corresponds to the primary phosphorylated form of Op18.

in $\mathrm{G} 0$, cell cycle analysis using acridine orange was performed (19). Acridine orange binds to both DNA and RNA, but has a different emission spectrum for each, thus allowing for differentiation between $\mathrm{G} 0, \mathrm{G} 1$, and $\mathrm{S} / \mathrm{G} 2 / \mathrm{M}$ phases (19). In a representative preparation of freshly isolated immature thymocytes that had a high level of Op18 (RII $=5.85), 93.4 \%$ of the cells were in $\mathrm{G} 0$, while $1.1 \%$ and $5.5 \%$ of the cells were in $\mathrm{G} 1$ and $\mathrm{S} / \mathrm{G} 2 / \mathrm{M}$ phase, respectively. After stimulation of this cell population with PMA and ionomycin for $48 \mathrm{~h}, 30 \%$ of the cells had elevated RNA content (G1) and $23 \%$ had elevated RNA and DNA content $(\mathrm{S} / \mathrm{G} 2 / \mathrm{M})$. Therefore, in the absence of mitotic stimulation, most double positive thymocytes were in G0 and a marked shift in cell cycle distribution can be demonstrated with mitotic stimulation.

To further determine the relationship between proliferative activity and $\mathrm{Op} 18$ expression, double positive thymocytes were cultured in media alone or with the addition of PMA and ionomycin for 48-96 h. In two separate experiments in which double positive cells were stimulated with PMA and ionomycin or incubated in media alone, the total amount of Op18 did not

Table I. Comparison of Op18 Protein Levels in Unstimulated Double Positive Versus Single Positive Thymocytes

\begin{tabular}{cllllll}
\hline & & \multicolumn{5}{c}{ Relative integrated intensity } \\
\cline { 3 - 7 } $\begin{array}{c}\text { Thymus } \\
\text { specimen }\end{array}$ & \multicolumn{1}{c}{ Phenotype ${ }^{*}$} & Op18 & Op18a & Op18b & Op18c & Total $^{\ddagger}$ \\
\hline \multirow{2}{*}{1} & Double positive & 8.77 & 1.44 & 0 & 0 & 10.21 \\
& Single positive & 1.61 & 0 & 0 & 0 & 1.61 \\
2 & Double positive & 6.37 & 1.99 & 0.19 & 0.13 & 8.68 \\
& Single positive & 1.53 & 0 & 0 & 0 & 1.53 \\
3 & Double positive & 5.09 & 1.28 & 0 & 0.08 & 6.45 \\
& Single positive & 0.97 & 0.20 & 0.13 & 0 & 1.30
\end{tabular}

* Double positive and single positive thymocytes were isolated by negative selection using anti-CD28 mAb or anti-CD1 mAb, respectively, as described in the text. ${ }^{\ddagger}$ Double positive versus single positive, $P=0.02$ (paired $t$ test). change after treatment (Table IV), although a 12-16-fold increase in $\left[{ }^{3} \mathrm{H}\right]$ thymidine uptake was observed (data not shown). In contrast, when single positive thymocytes were stimulated with PMA and ionomycin for $48 \mathrm{~h}$, induction of Op 18 could be demonstrated (Table IV), consistent with previous findings in mature peripheral $\mathrm{T}$ cells of an increase in Op1 8 levels late in G1 (5). It should be noted that with both double positive and single positive thymocyte populations, there was an increase in the proportion of phosphorylated to nonphosphorylated Op 18 with proliferation (Fig. 5, Table IV). In particular, the phosphorylated form Op18c was clearly observed in cells after $48 \mathrm{~h}$ of culture with PMA and ionomycin, while in the unstimulated cells, Op18c was at the limit of detectability.

\section{Discussion}

Previous reports examining the pattern of expression of $\mathrm{Op} 18$ in mature cells found that Op 18 was a proliferation-associated gene expressed following entry of cells into the cell cycle (1-5). In the case of normal lymphocytes, this meant that Op18 ex-

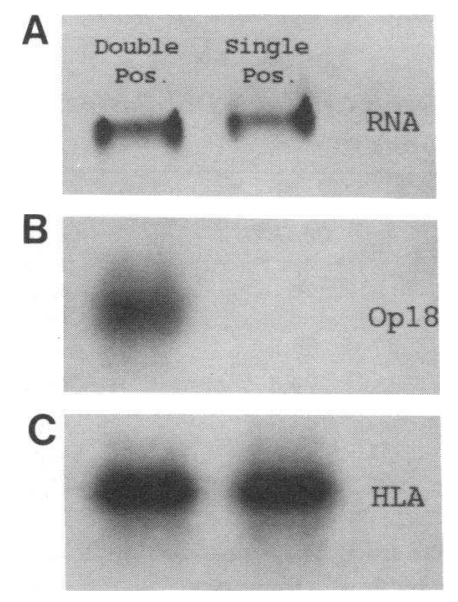

Figure 4. Op 18 gene expression in unstimulated double positive and single positive thymocytes. Total cellular RNA was isolated and equalized as described in the text. Northern blots were prepared and the filters were hybridized sequentially with cDNA probes specific for Op18 $(B)$ and HLA (C). $(A)$ depicts a photograph of ethidium bromide staining of the 28S RNA ribosomal band. 
Table II. Op18 Levels in Unstimulated

Immature Thymocyte Subsets

\begin{tabular}{ccccccr}
\hline & & \multicolumn{5}{c}{ Relative integrated intensity } \\
\cline { 3 - 7 } Phenotype $^{*}$ & $\mathrm{~N}$ & Op18 & Op18a & Op18b & Op18c & Total \\
\hline $\mathrm{CD}^{-}{ }^{-} \mathrm{CD}^{-}{ }^{-} \mathrm{CD} 8^{-}$ & 2 & 5.28 & 1.04 & 0 & 0 & 6.32 \\
& & 2.58 & 0.63 & 0.24 & 0 & 3.45 \\
$\mathrm{CD}^{-} \mathrm{CD}^{+} \mathrm{CD}^{+}$ & 3 & 8.18 & 2.70 & 0.09 & 0.20 & 11.16 \\
& & 6.83 & 0.95 & 0.10 & 0.10 & 7.98 \\
& & 4.84 & 1.39 & 0.20 & 0 & 6.43 \\
$\mathrm{CD}^{+} \mathrm{CD}^{+}{ }^{+} \mathrm{CD}^{+}$ & 2 & 6.66 & 1.78 & 0.14 & 0.03 & 8.60 \\
& & 3.77 & 1.44 & 0.16 & 0 & 5.37 \\
& & & & & &
\end{tabular}

* Each thymocyte subset was isolated as described in the text. Cell purity was monitored by flow cytometry.

pression could be induced after mitogenic stimulation through the TCR or with pharmacologic agents $(1,5)$. The data presented above indicate that in contrast to mature $T$ cells, in which Op18 is induced late in G1, immature resting thymocytes contain constitutively high levels of Op18. In addition, while PMA plus ionomycin stimulation of immature thymocytes induced proliferation, there was no further increase in total Op18 protein levels, and, therefore, Op18 expression in these cells was independent of proliferative activity or cell cycle distribution. In contrast, mature single positive thymocytes expressed very low basal levels of Op18, but as with peripheral blood T cells, Op18 was induced after treatment with PMA plus ionomycin.

The occurrence of Op18 protein at high levels in double positive thymocytes was associated with high levels of Op18 mRNA, indicating active expression of the Op18 gene rather than persistent $\mathrm{Op} 18$ protein from previous synthesis together with diminished turnover. Increased expression of the Op18 gene in immature thymocytes could result from high levels of specific transcription factors or could be the consequence of differences intrinsic to the gene itself (such as its methylation pattern ) in immature thymocytes versus resting $T$ cells. In view of the difficulty in undertaking studies of message stability in this cell population, posttranscription mRNA stabilization cannot be excluded as a contributing factor to high Op18 protein level.

While our data suggest that Op18 levels are linked to the maturation status of $T$ cells, at least two possibilities exist for the manner in which they are related. One possibility is that Op18 expression is directly linked to the differentiation pro-

Table III. Total Op18 Protein Versus Cell Cycle Distribution in Unstimulated $C D 4^{+} C D 8^{+}$Thymocytes

\begin{tabular}{cccc}
\hline $\begin{array}{c}\text { Thymus } \\
\text { specimen }\end{array}$ & Total Op18 & G0/G1* & S/G2/M* \\
\hline & RII & $\%$ & $\%$ \\
1 & 5.09 & 67.8 & 32.2 \\
2 & 5.50 & 79.4 & 20.4 \\
3 & 7.25 & 95.0 & 4.0 \\
4 & 5.85 & 85.0 & 15.0 \\
\hline
\end{tabular}

* Cell cycle analysis was performed using propidium iodide or acridine orange staining and analyzed by flow cytometry.
Table IV. Effect of PMA/Ionomycin Treatment on Phosphorylation of Op18

in Double Positive and Single Positive Thymocytes*

\begin{tabular}{llllll}
\hline & \multicolumn{5}{c}{ Relative integrated intensity } \\
\cline { 2 - 6 } Phenotype & Op18 & Op18a & Op18b & Op18c & Total \\
\hline Double positive & & & & & \\
Experiment 1, & & & & & \\
media, 0 h & 6.83 & 1.92 & 0 & 0 & 8.75 \\
PMA/ionomycin, 72 h & 2.49 & 1.77 & 0.45 & 0.31 & 5.02 \\
PMA/ionomycin, 96 h & 2.21 & 1.73 & 0.30 & 0.27 & 4.51 \\
Experiment 2, & & & & & \\
media, 0 h & 5.43 & 1.42 & 0.14 & 0 & 6.99 \\
PMA/ionomycin, 48 h & 3.09 & 2.89 & 0.89 & 0.14 & 7.01 \\
PMA/ionomycin, 96 h & 3.96 & 3.02 & 0.60 & 0.28 & 7.86 \\
Single positive & & & & & \\
Experiment 1, & & & & & \\
media, 0 h & 1.53 & 0 & 0 & 0 & 1.53 \\
PMA/ionomycin, 48 h & 1.30 & 0.87 & 0.20 & 0 & 2.37 \\
PMA/ionomycin, 72 h & 0.92 & 0.94 & 0.20 & 0.21 & 2.27 \\
Experiment 2, media, 0 h & 1.09 & 0.13 & 0 & 0 & 1.22 \\
PMA/ionomycin, 48 h & 1.19 & 1.17 & 0.67 & 0 & 3.03 \\
PMA/ionomycin, 96 h & 1.66 & 1.08 & 0.37 & 0 & 3.11 \\
& & & & & \\
& & & & &
\end{tabular}

* The cells were cultured for 48-96 $\mathrm{h}$ with PMA $(10 \mathrm{ng} / \mathrm{ml})$ and ionomycin $(250 \mathrm{ng} / \mathrm{ml})$ added to the culture medium.

gram of thymocytes independent of the thymic milieu. The other is that high levels of Op18 reflect the influence of the thymic microenvironment on gene expression, and that this microenvironment is different for double positive and single positive thymocytes. As there are no satisfactory in vivo or in vitro models of extrathymic $T$ cell development these two possibilities cannot be distinguished. They are not, however, mutually exclusive, and indeed the differences we observed in Op18 expression in double positive and single positive thymocytes may reflect differences in both their genetically controlled differentiation program and local environmental influences.

As noted above, several lines of evidence suggest that signal transduction involving Op 18 protein may play a role in cell proliferation. In addition, the Op18 gene promoter displays features associated with proliferation related genes (5). It lacks a TATA box, has a GC-rich promoter, and contains AP2 and
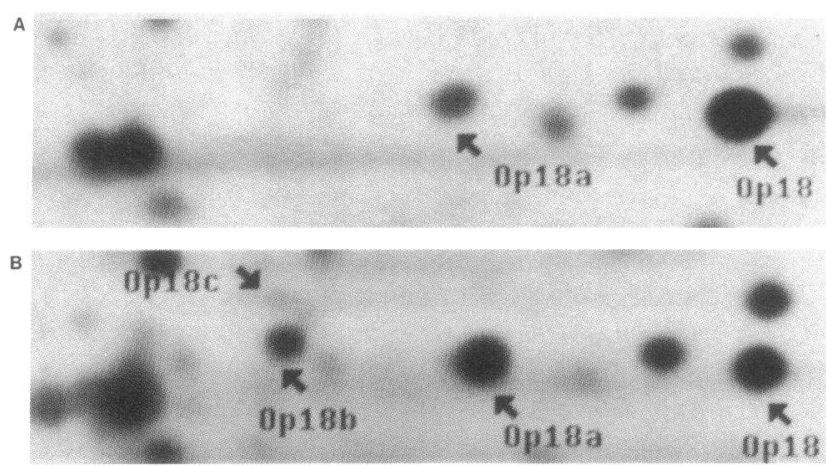

Figure 5. Phosphorylation of Op18 after mitogenic stimulation. Double positive thymocytes were analyzed by 2D-PAGE after insolation $(A)$ and after $48 \mathrm{~h}$ of culture with PMA and ionomycin $(B)$. The phosphorylated forms Op18 a, b, and c are evident after stimulation, as compared with unstimulated thymocytes. 
E2F binding sites. AP2 is a transcription factor that mediates the effects of two signal transduction systems known to be involved in growth control $(23,24)$. E2F is a transcription factor bound to $\mathrm{Rb}$ protein. $\mathrm{Rb}$ phosphorylation releases $\mathrm{E} 2 \mathrm{~F}$, which, in turn, activates proliferation genes such as $\mathrm{c}-m y c, \mathrm{~N}-m y c$, and c-myb (25).

Based on our findings to date, the following patterns of expression and/or phosphorylation of Op18 emerge. In the resting state, normal mature and immature thymocytes differ with respect to their content of Op18, and only mature thymocytes respond to mitogenic stimulation by increasing Op18 expression. However, interestingly, activation of either mature or immature thymocytes is associated with increased phosphorylation of Op18. In time course experiments, increased phosphorylation of Op18 is observed within 2 min of activation of peripheral blood T cells with OKT3 (9). Thus, it appears that both high levels of Op 18 protein, as well as its substantial phosphorylation, characterize both proliferating $T$ cells and proliferating thymocytes. This is in contrast to acute leukemic cells, including $T$ cell acute lymphoblastic leukemia, in which Op18 occurs at high levels without substantial phosphorylation.

The observation that blockade of Op 18 expression with antisense oligonucleotides inhibits cell cycle progression argues that Op 18 protein may be required for proliferation (8). However, based on studies of proliferating $\mathrm{T}$ lymphoblasts, an additional function has been suggested for Op18, namely that phosphorylation of Op 18 mediates down-regulation of DNA synthesis (11). According to this model, resting $\mathrm{T}$ cells contain very little Op18, and therefore the phosphorylation of Op18 after stimulation of resting cells exerts little effect. However, as Op 18 accumulates after cell activation, stimuli that phosphorylate Op18 (such as TCR ligation) will now have an inhibitory effect on cell proliferation. Although this model remains unproven, it is interesting to note that immature thymocytes express high levels of Op18 at rest, phosphorylate Op18 in response to TCR ligation (data not shown), and undergo activation-induced cell death via apoptosis after TCR stimulation (26). While a full elucidation of the role of the function of Op1 8 in cell proliferation remains to be determined, to the best of our knowledge, these studies constitute the first report that Op18 expression in hematopoietic cells is not coupled to cell cycle progression, and that high levels of Op18 protein or mRNA can be found in noncycling cells. Our data also suggest that the ordered expression of proliferation-associated genes seen in mature $\mathrm{T}$ cells may be disrupted during $\mathrm{T}$ cell maturation.

\section{Acknowledgments}

Dr. Gratiot-Deans is a recipient of an National Institutes of Health (NIH) National Research Service Award and an American Society of Transplant Physicians/Sandoz Pharmaceutical Corp. Research Fellowship Award. This work was also supported in part by NIH grants K01-DK01899 to L. A. Turka, as well as R01-CA26803 R01-CA32146 to $\mathrm{S}$. Hanash.

\section{References}

1. Hanash, S. M., J. R. Strahler, R. Kuick, E. H. Y. Chu, and D. Nichols. 1988. Identification of a polypeptide associated with the malignant phenotype in acute leukemia. J. Biol. Chem. 263:12813-12815.

2. Hailat, N., J. Strahler, R. Melhem, X. X. Zhu, G. Brodeur, R. C. Seeger, C. P. Reynolds, and S. Hanash. 1990. N-myc gene amplification in neuroblas- toma is associated with altered phosphorylation of a proliferation related polypeptide (Op18). Oncogene. 5:1615-1618.

3. Doye, V., F. Soubrier, G. Bauw, M.-C. Boutterin, L. Beretta, J. Koppel, J. Vandekerckhove, and A. Sobel. 1989. A single cDNA encodes two isoforms of stathmin, a developmentally regulated neuron-enriched phosphoprotein. J. Biol. Chem. 264:12134-12137.

4. Sobel, A., M.-C. Boutterin, L. Beretta, H. Chneiweiss, V. Doye, and H. Peyro-Saint-Paul. 1989. Intracellular substrates for extracellular signaling. Characterization of a ubiquitous, neuron-enriched phosphoprotein (stathmin). J. Biol. Chem. 264:3765-3772.

5. Melhem, R. F., X. X. Zhu, N. Hailat, J. R. Strahler, and S. M. Hanash. 1991. Characterization of the gene for a proliferation-related phosphoprotein (oncoprotein 18) expressed in high amounts in acute leukemia. J. Biol. Chem. 266:17747-17753.

6. Pines, J., and T. Hunter. 1989. Isolation of a human cyclin cDNA: Evidence for cyclin mRNA and protein regulation in the cell cycle and for interaction with $\mathrm{p} 34^{\text {cdc2 }}$. Cell. 58:833-846.

7. Furukawa, Y., H. Piwnica-Worms, T. J. Ernst, Y. Kanadura, and J. D. Griffin. 1990. cdc2 gene expression at the $G_{1}$ to $S$ transition in human $T$ lymphocytes. Science (Wash. DC.) 250:805-808.

8. Melhem, R. F., J. R. Strahler, N. Hailat, X. X. Zhu, and S. M. Hanash. 1991. Involvement of Op 18 in cell proliferation. Biochem. Biophys. Res. Comm. 179:1649-1655.

9. Strahler, J. R., B. J., Lamb, D. Ungar, D. Fox and S. Hanash. 1992. Cell cycle progression is associated with distinct patterns of phosphorylation of Op18. Biochem. Biophys. Res. Comm. 185:197-203.

10. Cooper, H. L., E. McDuffie, and R. Braverman. 1989. Human peripheral lymphocyte growth regulation and response to phorbol esters is linked to synthesis and phosphorylation of the cytosolic protein, prosolin. J. Immunol. 143:956963.

11. Cooper, H. L., R. Fuldner, E. McDuffie, and R. Braverman. 1989. T cell receptor activation induces rapid phosphorylation of prosolin, which mediates down-regulation of DNA synthesis in proliferating peripheral lymphocytes. $J$. Immunol. 146:3689-3696.

12. Cooper, H. L., R. Fuldner, E. McDuffie, and R. Braverman. 1990. A specific defect of prosolin phosphorylation in $\mathrm{T}$ cell lymphoblasts is associated with impaired down-regulation of DNA synthesis. J. Immunol. 145:1205-1213.

13. Stingl, G., K. C. Gunter, E. Tschachler, H. Yamada, R. I. Lechler, W. M. Yokoyama, G. Steiner, R. N. Germain, and E. M. Shevach. 1987. Thy-1 ${ }^{+}$dendritic epidermal cells belong to the T-cell lineage. Proc. Natl. Acad. Sci. USA. $84: 2430-2434$

14. Strominger, J. L. 1989. Developmental biology of T cell receptors. Science (Wash. DC.) 244:943-950.

15. Blackman, M., J. Kappler, and P. Marrack. 1990. The role of the T-cell receptor in positive and negative selection of developing T-cells. Science (Wash. D.C.) $248: 1335-1341$.

16. Turka, L. A., J. A. Ledbetter, K. Lee, C. H. June, and C. B. Thompson. 1990. CD28 is an inducible $T$ cell surface antigen that transduces a proliferative signal in $\mathrm{CD}^{+}$mature thymocytes. J. Immunol. 144:1646-1653.

17. Reinherz, E. L., and S. F. Schlossman. 1980. The differentiation and function of human T lymphocytes. Cell. 19:821-827.

18. Turka, L. A., P. S. Linsley, R. Paine III, G. L. Schieven, C. B. Thompson, and J. A. Ledbetter. 1991. Signal transduction via CD4, CD8, and CD28 in mature and immature thymocytes. J. Immunol. 146:1428-1436.

19. Darzynkiewicz, Z. 1990. Differential staining of DNA and RNA in intact cells and isolated cell nuclei with acridine orange. Methods Cell Biol. 33:285-298.

20. Strahler, J. R., R. Kuick, and S. M. Hanash. 1989. Two-dimensional polyacrylamide gel electrophoresis of proteins. In Protein Structure: A Practical Approach. T. E. Creighton, editor. IRL Press Ltd., Oxford, Eynsham, Oxon England. 65-92.

21. Kuick, R. D., S. M. Hanash, E. H. Y. Chu, and J. R. Strahler. 1987. A comparison of some adjustment techniques for the use with quantitative spot data from two-dimensional gels. Electrophoresis. 8:199-204.

22. Sood, A. K., D. Pereira, and S. M. Weissman. 1981. Isolation and partial nucleotide sequence of a cDNA clone for human histocompatibility antigen HLA-B by use of an oligodeoxy-nucleotide primer. Proc. Natl. Acad. Sci. USA. 78:616-620.

23. Imagawa, M., R. Chiu, and M. Karin. 1987. Transcription factor AP-2 mediates induction by two different signal-transduction pathways: protein kinase $\mathrm{C}$ and cAMP. Cell. 51:251-260.

24. Jones, N. C., P. W. J. Rigby, and E. B. Ziff. 1988. Trans-acting protein factors and the regulation of eukaryotic transcription: lessons from studies on DNA tumor viruses. Genes \& Dev. 2:267-281.

25. Mudryi, M., S. W. Hiebert, and J. R. Nevins. 1990. A role for the adenovirus inducible E2F transcription factor in a proliferation dependent signal transduction pathway. EMBO (Eur. Mol. Biol. Organ.) 9:2179-2184.

26. Smith, C. A., G. T. Williams, R. Kinston, E. J. Jenkinson, and J. J. T. Owen. 1989. Antibodies to CD3/T-cell receptor complex induce death by apoptosis in immature T cells in thymic cultures. Nature (Lond.). 337:181-184. 